\title{
Reflective Practice on Movie Scene Performances: Exploring Our
} Teacher Efficacy

\section{John Bankier \\ Kanagawa University \\ Joshua Brook Antle \\ Tsuda University}

\section{Reference Data:}

Bankier, J. \& Antle, J. B. (2020). Reflective practice on movie scene performances: Exploring our teacher efficacy. In P. Clements, A. Krause, \& R. Gentry (Eds.), Teacher efficacy, learner agency. Tokyo: JALT. https://doi.org/10.37546/JALTPCP2019-35

Reflective practice (RP) is an avenue to becoming an effective teacher. Collaborative dialogue on teaching practice increases critical engagement with RP and provides peer-support opportunities (Mann \& Walsh, 2017). In this paper we describe how our use of collaborative RP sessions impacted our sense of teacher efficacy. Two classes of Japanese university students selected, practised, and performed three short extracts from movies. We aimed to develop pronunciation, fluency, and enjoyment and engagement with English. In three teaching cycles, we engaged in collaborative dialogue sessions to reflect on teaching, discussing achievement of class goals and planned changes. RP sessions were audio recorded, transcribed, and qualitatively analysed for themes of teacher efficacy. We believe that reflecting and sharing our teaching practices led to an increased sense of our own capacity to effect positive teaching outcomes. Additionally, our response to negative teaching outcomes suggested increased confidence in our ability to adapt our teaching practice in response.

省察的実践 (RP) は、能力のある教師になるための手段である。教育実践に関して協働的な対話をすることで、省察的実践 への取り組みが高まりピアサポートの機会が作られる(Mann \& Walsh, 2017)。本稿では、協働的な省察的実践のセッション が教師効力感にどのような影響を与えるか考察する。2クラスの英語を学習している日本人大学生は 3 つの映画の报粋を選 び、練習し演じた教師は発音、流暢さ、楽しさ、英語を使うことへの取り組みを重視するよう心がけた。つの実践で、教師は 協㗢的な対話に参加し、クラス目標の到達や变更すべき点について話し合いながら授業について振り返った。セッションを録
音し、書き起こし、教師効力感に関して質的分析を行った。自分の教育実践を振り返り共有することで、プラスの教育効果を与 える能力が向上する感覚につながることが明らかになった。また、マイナスの教育効果に対し自分の教育実践を受けとめる能 カに自信を持てるようになった。

esearch shows that greater teacher efficacy contributes to teachers' persistence, engagement and commitment, resilience, and professional well-being (Chong \& Kong, 2012). Teachers with a greater sense of self-efficacy see difficulties as challenges rather than threats and respond by acquiring skills rather than focusing on personal deficiencies, approaching threatening situations "with the assurance that they can exercise control over them" (Bandura, 1993, p. 145). Teachers with a high sense of self-efficacy support the intrinsic interest and enjoyment of their students, rather than relying on extrinsic, negative sanctions such as grades to ensure student compliance (Bandura, 1993). As such, a strong sense of teacher self-efficacy leads to positive outcomes for both teachers and their students.

Teachers' self-efficacy is shaped by their social interactions in school communities, expressed as their sense of collective efficacy as members of such school cultures. Such collective efficacy beliefs also influence teachers' effort, persistence, and levels of stress and have been shown to have a measurable effect on student achievement (Goddard, Skrla, \& Salloum, 2017). In particular, teacher collaboration influences teachers' collective and self-efficacy by providing opportunities for teachers to emotionally and academically support each other through discussion and peer observation (Bruce \& Flynn, 2012;

Chong \& Kong, 2012; Goddard, Skrla, \& Salloum 2017). Among the many forms of peer collaboration, collaborative reflective practice (RP) has been a staple for professional development in many fields, including language education.

A concise definition for RP is "simply creating a habit, structure, or routine around examining experience" (Amulya, 2011, p. 2). Educational settings are particularly conducive to RP, and it is a common and important part of teacher education (Mann \& Walsh, 2017). Preservice teachers can benefit from RP by self-evaluating their lessons 
while also receiving feedback from experienced educators who have overcome, through experience, many of the issues new teachers will encounter. This self-evaluation and feedback can become the foundation upon which new teachers approach their profession. RP can help experienced educators refine their approach to aspects of teaching such as designing materials and structuring classes. Chassels and Melville (2009) described how in-service teachers benefitted from lesson study (a form of RP): "Through ongoing assessment and reflection, they could best determine a future course of learning for their students" (p. 751). They describe how teacher candidates and associate teachers improved the quality of their lessons and also benefited from a professional development perspective. Although RP can be an individual undertaking in which professionals selfevaluate, there are many benefits to collaboration during the reflection process.

This collaborative RP is accomplished through a dialogue between two or more professionals. Mann and Walsh (2017) endorsed collaboration: "This kind of dialogic approach to reflection can promote shared understandings and result in 'deep' rather than 'surface' awareness of pedagogy" (p. 189). The benefits of collaborating with a colleague on a shared topic of interest are numerous and easy to achieve. Wallace (1998) explained that "collaboration can ... generate richer input from the combined talents and insights of those involved" (p. 41). Mann and Walsh (2017) also mentioned that insights and understandings generated in collaborative RP can be acquired and appropriated. Collaborative RP enables teachers to efficiently address the needs of their students by using colleagues as a sounding board and resource, working together to address classroom issues. Studies have shown the particular benefits of collaborative RP. As mentioned above, Chassels and Melville (2009) described how a lesson study process "gave [teachers] greater insights into the needs of their students, the curriculum, teaching strategies, and the benefits of genuine collaboration among teachers" (p. 746). Collaboration thus allows teachers to understand a classroom issue more efficiently, which can lead to new insights regarding the students' needs and teaching strategies (Chassels \& Melville, 2009; Mann \& Walsh, 2017).

To explore these benefits of collaborative RP and its perceived impact on our teacher efficacy, we took part in three RP sessions across one semester. We selected one course that we both taught sections of, English Communication for Economics Majors 1 (ECEM1) at West Tokyo University (both pseudonyms). This was a required class within the Faculty of Economics taken by students who had opted out of the faculty's intensive academic English Global Programme (described in Bankier, 2019). Although students had been separated into two levels (Joshua: TOEIC 110-290; John: TOEIC 300-560), the administration's granting of students' requests to move classes and the unreliability of the TOEIC at lower score ranges meant both classes contained similarly mixed levels, roughly elementary to low intermediate. Using field notes as a basis, our RP discussions centred on a shared class activity (movie scene performances) as we reflected on our teaching, students' performance, and our perceptions of class outcomes. Three questions guided the study:

RQ1. Did reflective practice sessions contribute to a growing perceived teacher efficacy?

RQ2. Did we describe the outcomes of our teaching more positively as our sense of teacher efficacy increased?

RQ3. What changes to our own teaching practice occurred through reflective practice?

\section{Planning and Implementation}

Prior to the semester, we established guidelines for the movie scene performance activity. We felt it was not essential for the activities to be identical; however, our RP sessions would be more productive if the activities we were discussing had many similarities.

Consequently, we decided on the following guidelines:

- The students would perform three movie scene reenactments over the course of the 15-week semester, evenly spaced.

- These performances would account for $15 \%$ of their final grade.

- The students should submit transcripts prior to their performance.

- The students should have new partners each time.

- The students could not choose the same scene as another group.

- The original length of the scenes should be between 90 and 150 seconds.

- We should give the students a list of good qualities for the movie scenes (more dialogue, less action; easy to understand vocabulary; well-known movies).

- Students should also be shown how to find movie scripts online and be provided with a list of websites to use.

- We should allow the students to introduce new/difficult vocabulary prior to their performance.

Although the procedure evolved as a result of the RP sessions, in our first performance we adhered to the guidelines. Short portions of several classes were used to prepare the students for these performances. Before the first performance, the students brainstormed 
possible scenes in class. The class then discussed these scenes and the teachers gave feedback on their choices whenever possible. The teachers tried to steer the students towards possibilities that had the characteristics listed above. The students were then put in partners and told to decide on a scene for the next class. The following class the students touched base to make arrangements for preparing the script. In the third class, the students submitted their scripts for teacher feedback. Feedback centred on practicality of the scene for class performance. John also provided feedback on vocabulary and suggestions for replacing low frequency or idiomatic words to increase the audience's comprehension. The following class was for their performances. This process was repeated for the second and third performances with variations discussed below.

After both teachers had completed the first cycle of the movie scene performance, we met for our first RP session. Based on field notes, we discussed issues including assessment, rubrics, scheduling, student performance, and instructions. The sessions were conversational and touched on other topics such as students' perceived level of motivation, their effort, and our own feelings about the class and activity. This process was repeated for the second and third movie scene performances. The sessions lasted between 25 and 35 minutes. Our time constraints due to lesson preparation, assessment, and other responsibilities sometimes made it difficult to set aside time to conduct the RP sessions. However, preparing for sessions beforehand and limiting them to 35 minutes or less allowed us to fit collaborative RP into our busy schedules.

\section{Data and Analysis}

Data consisted of transcripts of the three RP sessions. These were transcribed by both authors and compared for accuracy. We used inductive analysis (Duff, 2008) to analyse the transcripts of the three RP sessions. In analysing the transcripts, our goal was not to conduct a further step in RP: in other words, to facilitate reflection on the RP process itself rather than to generate an objective representation of the data. After reading through the transcripts, we agreed on a list of potential codes that addressed our perceptions of the class and sense of teacher efficacy. The broad themes encompassed negative and positive perceptions of outcomes in the class and our degree of control over the learning environment. We then coded the transcripts individually, after which we compared and adjusted the coding. Using NVivo software (NVivo Pro 11, version 11.4.1.1064), we investigated relationships among the codes to further reflect on our changing perceptions and teacher efficacy beliefs. In the following section, we will describe the themes we jointly identified in the data.

\section{Reflection on RP Sessions}

A table in the Appendix summarizes how we judged our positive and negative perceptions of outcomes in our classes to have evolved across the three RP sessions. Broadly, we agreed that our perceptions shifted from negative to positive as changes to our teaching practice led to perceived improvements in students' performance of the movie scene activity. However, more important was increased recognition of our capacity to effect change through teaching, deemphasizing factors largely outside our control such as class size and students' out-of-class effort. In this section, we will discuss how collaborative reflection in the three sessions fostered our sense of teacher efficacy. Extracts from RP session transcripts will be presented using quotation marks.

In Session 1, we both thought that the first movie performance activity had not gone well, and we generally ascribed this to factors outside our control. Although some groups had chosen well-known scenes with familiar vocabulary and few idioms, others had chosen scenes neither they nor the audience could fully comprehend. Notably, we attributed the activity's lack of success primarily to students' "low" language level and failure to "memorize" their scripts. However, we did acknowledge that students needed more time and guidance. Joshua felt it was necessary to break up the activity across a larger number of classes and provide more teacher feedback on selection. However, John found giving feedback difficult due to his larger class size and lack of time outside class. Although we did not find a solution to these difficulties, we shared two new teaching ideas: Joshua would give feedback to students after the performance with a rubric to encourage memorization, and we would both include a one-minute introduction of the scene in Japanese to improve audience comprehension and interest. In short, although we described class outcomes in terms of factors largely outside our control, we also began to share teaching ideas to address these difficulties.

In Session 2, our perceptions of class outcomes differed. Joshua felt that, although some problems remained, the activity had been much more successful than the first performance. In contrast, John felt students' memorization had been poorer. However, the ideas we shared in the previous session had had positive outcomes. After listening to Joshua, John had made time to take in students' scripts and give feedback, leading to more appropriate scene choice and vocabulary level, although it had been challenging to find time to give feedback to all groups. The broken-up performance process also led to more comprehensible scenes and better group-work dynamics for Joshua's groups. In particular, his use of in-class practice sessions with teacher feedback encouraged students to memorize the scenes before their actual performance date. Importantly, even the negative perceptions suggested our increasing sense of teacher efficacy. Although 
John characterized his students as "not very motivated ... in general," we had begun to notice how our teaching contributed to negative outcomes. John believed that his assessment rubric had allowed students to achieve a B grade without memorizing the scripts, particularly as the students had held the scripts during the performance. As Joshua pointed out, the students were responding to the conditions set up by us, doing what would lead to positive outcomes for them. Although some changes we made led to perceived negative outcomes, nonetheless our collaborative reflection encouraged us to see these changes as within our control.

In Session 3, although our perceptions of class outcomes were ambivalent, our increased teacher efficacy was apparent in our discussions. Factors outside our control remained important to perceived success of the movie performance activity. John mentioned that students who "were good in ... the other movie performances were good again" although some others had, again, not made an effort. Unlike Session 2, Joshua felt the activity had been less successful. He thought some groups had been "really lazy" in practicing for their performance; however, he attributed this to the "dog days" at the end of semester, suggesting the reflective discussions had encouraged us to see factors outside our control as temporary or transient rather than inevitable. In contrast, John felt the third performance had been his most successful by far. Responding to his students' attraction to anime, John had made a "fairly big change" by reframing the performance activity as a movieoke (Erten, 2016) in which students performed their own English translation of the Japanese dialogue over an original animated scene playing in the background. In contrast to previous sessions, John's impressions of this final performance were more positive, particularly one group who had selected an amusing scene from the animated children's television programme, Kureyon Shinchan. By modifying the activity from a performance to a translation activity and moving the focus from potentially unknown English-language films to well-known animation, John dealt with many of the language and motivation issues discussed earlier. Importantly, this led Joshua to notice that our previous approach had allowed students to "muck their way through and get [a passing grade]" without paying attention to the rhythm or effect of the performance on the audience. In other words, the movieoke performance could encourage even "lazy" students to make an effort by appealing to their interests. Joshua decided to use the movieoke activity in future semesters. Our growing sense of efficacy encouraged us to modify the movie performance activity in response to students' intrinsic interest and enjoyment. The discussion showed how RP can foster teacher efficacy and facilitate realizations about teachers' own practice that facilitate real changes to practice.

\section{Discussion and Conclusions}

Returning to the guiding questions, we found that the reflective practice sessions firstly did have a positive influence on our sense of teacher efficacy. We had more confidence in overcoming environmental constraints such as class size and students' language level and motivation. We placed more focus on things we did, as opposed to blaming the environment and factors not really under our control.

To address the second question, our perceptions of class outcomes were more ambivalent. Although John broadly felt that the performances had improved each time, Joshua was much less satisfied with the third performance than the second. However, we attributed class outcomes to different factors as our perceptions shifted over the course of the three sessions, associating negative outcomes not with class size or students' language level but our own choices as teachers. For instance, in the final RP session, we both described how the students' English level was not a hindrance to their movie scene performance. The RP sessions led to an increased sense of effectiveness as a teacher even when outcomes were not always perceived positively, and we finished the sessions with a positive outlook toward our future teaching.

The final question focused on the pedagogical changes to our teaching practice. These changes were present in the latter two movie scene performances. Moreover, we believe that these changes have positively influenced our overall teaching practice and will improve our future classes and activity design. Three examples of pedagogical changes from this study are the use of assessment rubrics, the face-to-face feedback sessions among teacher and students, and the movieoke activity. Joshua took John's suggestion of using a rubric. The rubric was shown to the students before their second and third performances, and we believe it created a better understanding on the students' part of the assessment criteria and the importance of their choice of movie scenes. Student accountability was increased over the course of this study, and we believe this also led to improvements in the final performances. Accountability can be seen in the feedback sessions suggested by Joshua, in which the students memorized their scripts in advance of their final performances. The movieoke activity used by John and adopted by Joshua in future semesters appealed to students' intrinsic interests and enjoyment of animation. The activity came about partly as a result of the RP discussions and John's realization that his assessment rubric had had a negative effect on outcomes.

Overall, the RP sessions were beneficial and a productive use of time. We borrowed strategies from each other and put these into practice with positive results. Additionally, the process of discussing problems and weak points lead to new approaches for implementing this activity. Furthermore, using qualitative data analysis to reflect on 
the sessions as we wrote this paper constituted a further step in the RP process. The analysis gave us a broader view, encouraging us to perceive how our sense of teacher efficacy had been shaped by the discussion sessions. We strongly feel that these changes to our teaching practice and perceived development of teacher efficacy justified the relatively modest amount of time spent. We thus support the view that collaborative RP is a powerful tool in fostering beliefs in teacher efficacy that are grounded in concrete development of (shared) teaching practice.

\section{Bio Data}

John Bankier has recently taken up a new position at Kanagawa University. He completed his MSEd TESOL from Temple University, Japan Campus and his PhD in linguistics from Lancaster University. His research interests include the theory of language socialisation, individual networks or practice/social networks, and development of academic English, particularly writing.

Joshua Brook Antle has been with Tsuda University since 2015. He also completed his MSEd TESOL from Temple University, Japan Campus and his PhD in applied linguistics from Aston University. His research interests include learning and assessment of vocabulary and extensive listening. He lives in Saitama and enjoys winter sports and hiking.

\section{References}

Amulya, J. (2011). What is reflective practice? Retrieved from https://www.communityscience.com/ images/file/What\%20is\%20Reflective\%20Practice.pdf

Bandura, A. (1993). Perceived self-efficacy in cognitive development and functioning. Educational Psychologist, 28(2), 117-148. https://doi.org/10.1207/s15326985ep2802_3

Bankier, J. (2019). Second language academic literacy socialisation through individual networks of practice: An ethnographic account of learning to write in an academic English programme in Japan [Unpublished doctoral dissertation]. Lancaster University, Lancaster, England.

Bruce, C. D., \& Flynn, T. (2012). Assessing the effects of collaborative professional learning: Efficacy shifts in a three-year mathematics study. Alberta Journal of Educational Research, 58(4), 691-709. Retrieved from https://journalhosting.ucalgary.ca/index.php/ajer/

Chassels, C., \& Melville, W. (2009). Collaborative, reflective, and iterative Japanese lesson study in an initial teacher education program: Benefits and challenges. Canadian Journal of Education, 32(4), 734-763. Retrieved from https://cje-rce.ca/\#
Chong, W. H., \& Kong, C. A. (2012). Teacher collaborative learning and teacher self-efficacy: The case of lesson study. The Journal of Experimental Education, 80(3), 263-283.

https://doi.org/10.1080/00220973.2011.596854

Duff, P. A. (2008). Case study research in applied linguistics. New York, NY: Routledge.

Erten, I. H. (2016). Movieoke: Bringing movies to the language classroom for meaningful language practice. Presentation delivered at Sinav College International ELT Convention, Ankara, Turkey.

Goddard, R. D., Skrla, L., \& Salloum, S. J. (2017). The role of collective efficacy in closing student achievement gaps: A mixed methods study of school leadership for excellence and equity. Journal of Education for Students Placed at Risk (JESPAR), 22(4), 220-236.

https://doi.org/10.1080/10824669.2017.1348900

Mann, S., \& Walsh, S. (2017). Reflective practice in English language teaching: Research-based principles and practices. New York, NY: Routledge.

Wallace, M. J. (1998). Action research for language teachers. Cambridge, England: Cambridge University Press.

Appendix

Perceptions of Class Outcomes During Reflective Practice Sessions

\begin{tabular}{lll}
\hline \multicolumn{1}{c}{ Negative perceptions } & \multicolumn{1}{c}{ Positive perceptions } \\
\hline 1 & $\begin{array}{l}\text { Large class size } \\
\text { John: I might be able to do that in } \\
\text { class, but l've got so many students ... } \\
\text { so I don't really have time. }\end{array}$ & $\begin{array}{l}\text { Students' effort during performances } \\
\text { John: When they did the scene, } \\
\text { partly because the student who was } \\
\text { doing it, was being Harry Potter, } \\
\text { was very good, very, very good... The } \\
\text { audience could follow what he was } \\
\text { saying. }\end{array}$ \\
& $\begin{array}{l}\text { John: What l'd really like ideally, } \\
\text { ideally would be to have the students } \\
\text { show the scene in class with Japanese } \\
\text { subtitles ... but I don't think it's really } \\
\text { practical with 10 [groups]. }\end{array}$ \\
\hline
\end{tabular}




\begin{tabular}{|c|c|}
\hline Negative perceptions & Positive perceptions \\
\hline Lack of time & Students' scene selection choices \\
\hline $\begin{array}{l}\text { John: “[What] l'd like to do really } \\
\text { - I just haven't got the time - at } \\
\text { the moment ... is like taking their } \\
\text { scripts, go through them, give them } \\
\text { suggestions. }\end{array}$ & $\begin{array}{l}\text { Joshua: Another group chose } \\
\text { Spiderman, which was the scene } \\
\text { with Peter Parker talking to his } \\
\text { uncle Ben ... that was a great } \\
\text { choice because it was not difficult } \\
\text { to understand and it was famous } \\
\text { enough... I'm going to highlight that } \\
\text { in my next class. }\end{array}$ \\
\hline \multirow{3}{*}{$\begin{array}{l}\text { Students' low language level } \\
\text { Joshua: I have some students who } \\
\text { are quite lower level actually... the } \\
\text { language within the transcript was } \\
\text { very difficult. }\end{array}$} & Instructions that facilitated classroom \\
\hline & management and comprehension \\
\hline & $\begin{array}{l}\text { Joshua: If we have it broken into } \\
\text { more parts, then there is kind of } \\
\text { more... opportunity [to memorize it]. }\end{array}$ \\
\hline \multicolumn{2}{|l|}{ Students' lack of effort to memorize } \\
\hline \multirow[t]{2}{*}{$\begin{array}{l}\text { Joshua: The memorization was a } \\
\text { big problem in my class and some } \\
\text { - some of it was terrible ... they just } \\
\text { read it. }\end{array}$} & \multirow{6}{*}{$\begin{array}{l}\text { John: One minute to introduce the } \\
\text { scene in Japanese. Yeah, that helps a } \\
\text { bit, it didn't help a huge amount, but } \\
\text { some of the scenes it did make quite } \\
\text { a big difference. } \\
\text {... } \\
\text { Joshua: I had them do the } \\
\text { introduction in English, but maybe } \\
\text { l'll let them do it in Japanese. }\end{array}$} \\
\hline & \\
\hline Students' choice of inappropriate scenes & \\
\hline $\begin{array}{l}\text { Joshua: To be honest, it didn't go } \\
\text { well for my class... one of the biggest } \\
\text { problems was they chose scenes } \\
\text { which were really difficult. }\end{array}$ & \\
\hline Lack of assessment & \\
\hline $\begin{array}{l}\text { Joshua: Okay. I notice you have a } \\
\text { rubric here ... I didn't create a rubric } \\
\text { and I regretted it. }\end{array}$ & \\
\hline
\end{tabular}

\begin{tabular}{|c|c|c|}
\hline & Negative perceptions & Positive perceptions \\
\hline \multirow{7}{*}{$\begin{array}{l}\text { Session } \\
2\end{array}$} & Large class size & \multirow{2}{*}{$\begin{array}{l}\text { Students' effort in writing or revising } \\
\text { scripts }\end{array}$} \\
\hline & Joshua: I think that having them & \\
\hline & $\begin{array}{l}\text { present it to you before they do the } \\
\text { final thing, makes a difference in } \\
\text { terms of their memorization, effort } \\
\text { to memorize. } \\
\ldots \\
\text { John: My problem is that I've got a } \\
\text { huge number of students. I've got } 21 \text {. }\end{array}$ & $\begin{array}{l}\text { John: I took it away because I could } \\
\text { not get through all of them in class } \\
\text { and I gave them feedback and I gave } \\
\text { it back to them... What I found was } \\
\text { the scripts they gave me were already } \\
\text { pretty decent. I didn't actually do } \\
\text { much editing. }\end{array}$ \\
\hline & Students' lack of motivation to learn & Students' choice of appropriate scenes \\
\hline & $\begin{array}{l}\text { English } \\
\text { John: I also think it is this thing. } \\
\text { They are not very motivated } \\
\text { students in general. }\end{array}$ & \multirow[t]{3}{*}{$\begin{array}{l}\text { Joshua: First of all, the scenes } \\
\text { they selected were way more } \\
\text { comprehensible. }\end{array}$} \\
\hline & Joshua: Yup. & \\
\hline & $\begin{array}{l}\text { John: So, but they don't mind } \\
\text { getting a B. So if you can get a B } \\
\text { and they can see you can get a B if } \\
\text { your scene is pretty good and you } \\
\text { speak very clearly even if you don't } \\
\text { actually bother to make any eye } \\
\text { contact. }\end{array}$ & \\
\hline
\end{tabular}
Joshua: To be honest, it didn't go well for my class... one of the biggest which were really difficult.

Joshua: Okay. I notice you have a rubric here ... I didn't create a rubric retted it. 


\section{Negative perceptions}

Assessment discouraging memorization John: I think my assessment might have contributed to the lack of memorization. ...Technically, you could get top marks for fluency without memorization.

$\cdots$

Joshua: Like, if I put myself in thei shoes and if I have a script, even if I have it memorized, l'll probably look at the script.

Lack of "strictness" in instructions John: I should have just said no script.

Joshua: Yeah. I hold the script myself and I give them prompts if they are struggling.

...

John: I think it's things I have done rather than things they have done that has contributed to that. I think it is not being strict enough about the scripts when they are doing the role plays.

\begin{tabular}{|c|c|c|}
\hline & Negative perceptions & Positive perceptions \\
\hline \multirow{3}{*}{$\begin{array}{l}\text { Session } \\
3\end{array}$} & Some students' lack of effort at the & Some students' continued effort \\
\hline & end of semester & John: The students who were good \\
\hline & $\begin{array}{l}\text { Joshua: A couple of groups } \\
\text { were really lazy with their scene } \\
\text { selection, I can tell from just, just }\end{array}$ & $\begin{array}{l}\text { in the role-plays and the other } \\
\text { movie performances were good } \\
\text { again... }\end{array}$ \\
\hline
\end{tabular}

copying something, something,

anything... I think that might

have been just because they were winding down, it was kind of the dog days.

John: You find, do you think having them presenting it to you before they do the big final thing makes a difference in terms of their memorization?

Joshua: Yeah. I think it does... I think they almost all want to show me they tried so they all had made some effort to memorize it.

Class scheduling that facilitated all stages

Joshua: I think the biggest thing that helped was my schedule. I basically made a four, a five class process I guess. I would introduce it, put them in partners. And then the next class, I would give them a couple of minutes to touch base and make sure what scene they were going to choose.
Instructions discouraging performance Joshua: The way I approached it, even if they didn't put much effort into it, they knew - you know, they could speak and muck their way through and get [a passing grade] yours they have to put the work in, like there's no way around it.
Students' choices matching teacher expectations

John: One [group] did Kureyon Shinchan... I said to them after they finished, this is exactly what I am wanted - exactly what I imagined it was going to be like. 
Assessment facilitating some aspects of

performance

Joshua: They saw that timing

and scene selection were quite

important.

Instructions facilitating some aspects of

performance

Joshua: That's something that

anyone can do, even the low-level

students can choose a good scene

and can make sure it's at least 90

seconds.

John: I made a fairly big change...I

did like a movieoke, karaoke thing,

...Unless they'd practised really very

well because the timing will be off

in the scene, so a lot of the groups

were actually looking at the video

and trying to match what they were

saying, and not looking at the scripts. 